\title{
Athlete's Dependence and Acceptance on the Language of Health Article Writing in the Press
}

Mohd Hazreen Shah Hassan, Sharil Nizam Sha'ri, Akmar Hayati Ahmad Ghazali, Zaitul Azma Zainon Hamzah, Alhaadi Ismail \& Nur Afiqah Ayub

To Link this Article: http://dx.doi.org/10.6007/IJARBSS/v11-i4/9707 DOI:10.6007/IJARBSS/v11-i4/9707

Received: 19 February 2021, Revised: 20 March 2021, Accepted: 02 April 2021

Published Online: 22 April 2021

In-Text Citation: (Hassan et al., 2021)

To Cite this Article: Hassan, M. H. S., Sha'ri, S. N., Ghazali, A. H. A., Hamzah, Z. A. Z., Ismail, A., \& Ayub, N. A. (2021). Athlete's Dependence and Acceptance on the Language of Health Article Writing in the Press. International Journal of Academic Research in Business and Social Sciences, 11(4), 604-617.

\section{Copyright: @ 2021 The Author(s)}

Published by Human Resource Management Academic Research Society (www.hrmars.com)

This article is published under the Creative Commons Attribution (CC BY 4.0) license. Anyone may reproduce, distribute, translate and create derivative works of this article (for both commercial and non-commercial purposes), subject to full attribution to the original publication and authors. The full terms of this license may be seen at: http://creativecommons.org/licences/by/4.0/legalcode

Vol. 11, No. 4, 2021, Pg. 604 - 617

Full Terms \& Conditions of access and use can be found at http://hrmars.com/index.php/pages/detail/publication-ethics 


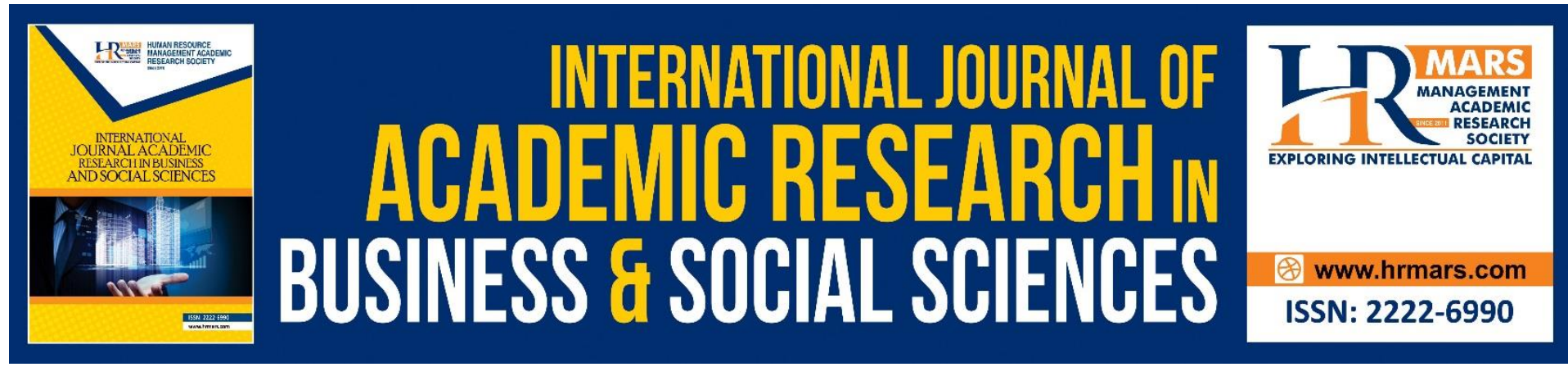

\title{
Athlete's Dependence and Acceptance on the Language of Health Article Writing in the Press
}

\author{
Mohd Hazreen Shah Hassan, Sharil Nizam Sha'ri, Akmar \\ Hayati Ahmad Ghazali, Zaitul Azma Zainon Hamzah, Alhaadi \\ Ismail \& Nur Afiqah Ayub \\ Department of Malay Language, Faculty of Modern Language and Communication, \\ Universiti Putra Malaysia, 43400 Serdang, Selangor, Malaysia, Department of \\ Communication, Faculty of Modern Language and Communication, Universiti Putra \\ Malaysia, 43400 Serdang, Selangor, Malaysia, SMK Sijangkang Jaya, 2, Jalan Langsat, Taman \\ Seri Medan, 42500 Telok Panglima Garang, Selangor, Malaysia. \\ Email: mohdhazreenshahputra@gmail.com
}

\begin{abstract}
Malaysians today are beginning to realize the importance of improving their health both physical fitness and mental intelligence. Nowadays, the press is one of the mediums that can be accessed by the public to obtain health information through health articles. Therefore, this study was conducted to examine the extent to which athlete's dependence on newspaper health articles to obtain information related to health aspects as well as their acceptance of the language used of health article writing in newspapers. This study uses two methods, namely field study (80\%) and content analysis (20\%). The research tool in this study is a questionnaire, distributed to 50 respondents consisting of university / state and national athletes. The findings of the study show that the dependence of athletes on health articles in the press is at an excellent level with a mean score of 4.24 (standard deviation: 0.65). Besides, the level of acceptance of athletes towards the language used of health articles writing in the press is at a good level, with a mean score of 4.09 (standard deviation: 4.41). These findings indicate that the newspaper is an option among athletes to obtain information related to health, and the language used in the newspaper is easy to understand and able to influence their cognition, feelings, and behavior.
\end{abstract}

Keywords: Press, Health Articles, Athletes, Dependence, Acceptance, Language.

\section{Introduction}

Newspapers are one of the broadest forms of mass media closed to the public apart from radio, magazines, and television because newspapers are seen to have their advantages over other forms of mass media (Amir, 2005). The advantage stated by Amir (2005) refers to the ability of the press as the dissemination of information, easy to obtain, and even readers can make choices according to their desire to read any segment contained in the newspaper. To this day, newspapers are still relevant to be used as general reading material for all walks of life, regardless of age (Hassan, 2017). Normally, newspaper articles has many types of writing. 
According to Masri and Ayob (2002), writing in a newspaper is known as journalistic writing. There are five types of journalistic writing which consist of news writing, article writing, interview writing, review writing and even report writing. These five writings have their functions and writing style that different from each other (Masri \& Ayob, 2002).

Apart from the variety forms of journalistic writing found in newspapers, Somiah et al. (2010) stated that the content in the newspaper is also diverse, as each newspaper has allocated various segments or includes specific issues for public viewing and reading. Segments related to health aspects are no exception to be one of the part contained in the press. Information dissemination related to health aspects in the press is more to the writing of journalism in the form of articles. If we look at mainstream newspapers such as Berita Harian (BH) and Utusan Malaysia (UM), newspaper publishers have introduced special segments to discuss any issues related to health aspects to the public. For $\mathrm{BH}$ newspapers, publishers have introduced Healthy segments which are published periodically every Saturday, while UM newspapers have introduced Health segments which are published every Sunday. Both of these segments, allow the public to obtain varied information about the world of health.

\section{Article Writing}

Samani (1997) describes the writing of an article as 'a detailed writing about a real thing that allows the prominence of the writer's personality either through the views expresses, about the questions work on or through the style he uses'. Amir (2006) in his book, Buat Duit dengan Menulis states that "... an article is writing that is longer than news has human elements, interesting, creative and subjective. It is processed based on interviews, observations and experiences from news, issues, events, incidents or any aspect of life that has been and is happening. The purpose is to inform, educate, persuade, influence, and entertain the reader. Readers may acquire new information, knowledge, and experiences or strengthen existing ones. Readers may be happy, satisfied, angry, anxious, amused, amazed, sad and so on as a result of reading the article". According to Itule and Anderson (2007), the article defined as writing the people profiles as news, describes the events that move the news, analyzes what is happening in the world, country and society, and teaches society to do something. He added that articles writing suggest better ideas in a complex world, examining trends in an ever-changing society, bringing people into another 'realm', and entertaining audiences. In short, essay writing is based on news writing as a source of writing, highlighting human aspects and humanity, the essence based on the truth and the author is free to express his views in the writing and able to stimulate the mind and feelings of readers (Hassan, 2017).

\section{Health, Society and Athletes}

Awan and Rajab (2010) explained that Malaysian society today is beginning to realize the importance of improving their health both physical fitness and mental intelligence regardless of age. Awan and Adnan (2011) stated that the information related to a healthy lifestyle through the press is able to instill positive values in society and give stability in the value of community life in terms of physical, while having a positive impact on the society spiritual life. In this regard, knowledge related to health aspects is very important for all walks of life, including athlete.

According to de Fleur and Ball-Rokeach (1992), audiences are easily stimulated when information displayed in the mass media is closely related to their living environment, thus, it can influence them to change their cognitive, affective and behavioral. Cognitive effects refer 
to the audience ambiguity of attitudes, beliefs and values. Affective effects (feelings) refer to the effect of the media message towards feelings and emotional responses of the audience when receiving information or messages conveyed by the media (de Fleur \& Ball-Rokeach, 1992). The effect can be seen in several aspects, namely immunity, fear, anxiety, enthusiasm as well as disaffection. Besides, the effect on behavior refers to the activation and inactivity aspects.

Therefore, health phenomena in the lives of athletes are two things that are difficult to separate. Good health care among athletes includes physical fitness and mental intelligence. Both of these aspects will determine the athletes' performance before, during and after being involved in any tournament. According to Awan and Abdul Rajab (2010), physical fitness is very important in the life of an athlete, in fact, it can reflect the athlete's personality about life and the ability to work more efficiently and effectively. Even though, athletes are usually controlled and monitored by the National Sports Institute (ISN), they must know and learn about health on their own either through formal or informal education. Thus, the newspaper is one of the right media for athletes to act as their reference sources and obtaining information about health.

\section{Publications and Languages Press}

Nowadays, newspaper publications especially in questioner have lost their grip and keen to influence the audience, due to the unreliable and unpersuasive writers (Sha'ri, 2010), even the press is facing challenges to educate society and develop the nation's culture due to the uncertain role (Amir, 2005). According to Ghazali and Omar (2014), the content in the newspaper these days is unable to attract the audience interest to read because it does not suit their personalities and needs. Further, Adnan (2015) stated that the content of the mass media is not monitored carefully, it is able to deviate in negative directions, such as spreading slander and lies, but it is also able to damage the individuals and national reputation as well as national integrity.

In terms of language, Idrus and Hamzah (2011) found that there are still consist certain errors in language and journalism writing, including articles writing. Meanwhile, the weaken of languages still occur in journalism writing, especially in terms of grammar, lexical and orthographic (Wahab \& Hamid, 2015; Wahab, 2012; Sha'ri, 2010; Suroso, 2010; Ghani \& Ibrahim, 1987). This indirectly shows the occurrence of additional language in journalism writing will lead to ambiguity and confusion of meaning to the audience. Wahab (2012) explains that the additional language in journalistic writing should be avoided to provide more comprehensive understanding to the reader, not only in terms of content, but also in the context of language used.

In addition, Fadzillah (2016) shows that the pattern of writing influenced by its language style. However, unstructured writing across with an article pattern and the appropriate language style will hinder the understanding among the audience. Furthermore, the process of creating the article title is also unable to attract the audience interest in reading, thus, it is creating more confusion and the content not really convey (Fadzillah, 2016). The title of the article that is not interesting and hanging causes the lack of reader attention, while Yaakob (2008) explained that the title will attract the audience to read a journalism writing in the newspaper. Hassan (2017) recognizes that health article in the press often uses the jargon term and it will make difficult for the audience to well understand the content if it is not coming with a proper definition or explanation related to the term. 
Therefore, this study was conducted to examine the extent to which athlete's dependence on health articles in the press to obtain health information and their acceptance of the used of the language of health articles writing in the press.

\section{Literature Review}

Ismail (2008) explained that mass media such as print media should be responsible in shaping the reader's perception of the real situation. Due to that, Ismail (2008) examined the extent to which news writing and articles on anti-smoking campaigns risk communication in Berita Harian and Utusan Malaysia have succeeded in playing their role in influencing society. Ismail (2008) used the content analysis method in analyzing the study data on 372 newspaper manuscripts, namely 186 for Berita Harian and 186, Utusan Malaysia, which was published on 1 July until 31 December 2004. The results of the study found that the total positive news direction is 34 manuscripts (10UM: $24 \mathrm{BH}$ ), 3 manuscripts for neutral news (2UM: $1 \mathrm{BH}$ ) and negative news is 20 manuscripts (10UM: 10BH). Overall, the outcomes of Ismail (2008) research on Berita Harian and Utusan Malaysia newspapers dated 1 July to 31 December 2008 found that there are differences in terms of news prominence, news direction and smoking risk news categories, in fact these two newspapers do not publish news on smoking effectively and just merely on it. Ismail (2008) in his study concluded that risk news needs to get more attention, especially the media because the media is the closest channel in conveying information related to health and risk environment to the public.

In addition, Ariffin (2010) explained that the mass media not only acts to report news, but plays a role in educating and giving specific guidance to the public. The reliance of the audience in the mass media such as newspapers hits other media channels due to the validity news presented by the press more up to date. The results of Ariffin (2010) study found that the mass media, especially television and newspapers play a significant role in helping to deal with snatch theft, in fact the majority of respondents stated that the content of the mass media featuring snatch theft is true, even the media has a social responsibility to convey true and reliable news to the audience.

Next, a study done by Samani, Maliki and Rashid (2011) entitled 'Literasi Media: Ke Arah Melahirkan Pengguna Media Berpengetahuan' shows that the level of literacy among media users is at a low level due to several factors that shape their life such as family background, environmental as well as standards of living. A study of media literacy in the print media, especially newspapers found that users choose newspapers as a source to add knowledge and get more information. Consumers were also found to receive information displayed in the press as a positive, in fact some users said there was no negative value in the news content displayed.

According to Zawawi and Chang (2013), anything outlined in the newspaper will form an opinion and understanding among readers because it can collect and form a general view towards some issues displayed in the press. As such, a study by Zawawi and Chang (2013) has discussed the impact of determining the news outlined found in newspapers focusing on issues related to public safety. In the meantime, the impact of determining the public safety news outlined is evaluated from two angles, namely from the point of view of reader cognition and also expression. The results of the study of Zawawi and Chang (2013) found that positive shaped reporting has a deeper impact in terms of cognition and expression than negative reporting, in fact, this study also revealed that most newspapers today tend to use the negative form reporting to attract interest readers. Zawawi and Chang (2013) also stated 
that the framing of negative news in influencing the reader is not able to have any effect on the cognition and expression of the reader.

Besides, Ghazali and Omar (2014) conducted a study related to 'Keperluan Pembaca Remaja Terhadap Kandungan Akhbar' and stated that the level of newspaper reading among adolescents at this time showed a decline rate because the content is not meeting their reading needs. As such, a study conducted by Ghazali and Omar (2014) has examined the needs of adolescent readers on the newspaper content that covering the aspects of cognitive, emotional, personal, social and emotional release needs. The results of the study found that the readers able to accept or reject the newspaper in order to meet their needs are depending on the newspaper content that have various dimensions of the material published.

In addition, the media is also one of the most important communication medium in human life, in fact, it is significant in providing guidance to behavior, shaping life and influencing the norms of human life (Awang, 2015). In the meantime, society daily lives already attached to the media until it is able to influence their life pattern. Mustafa et al. (2010) also show that mass media such as newspapers, television and internet have the ability to deliver what is right and wrong in a previous compilation, but, nowadays, the audience can choose to accept or not the content published by the media.

According to Sha'ri and Hassan (2016), newspapers are able to increase knowledge and enhance the maturity of their readers, including campus newspapers. The use of language that is easy to understand and the content of the news is generally suitable to be used as reading material for every life of society. In addition, a study by Wahab and Hamid (2015) recognize that, there are four aspects of language that fail to attract the audience to the news text as well as delivering information also not reach to the target group, which is vocabulary words used; use of remuneration; use of acronyms; and borrow words use. Abdul Wahab (2012) states that, the use of clear and accurate language in the content to be conveyed is important to ensure the audience can understand the subject matter. Therefore, the additional element in journalism writing should be avoided to provide a comprehensive understanding to the audience (Abdul Wahab, 2012). This is because it will hinder the accuracy of the sentence and prevent the reader's understanding of the newspaper content (Wahab, 2012).

A study by Rakhmatova (2020) examines the use of colloquial language in The Daily Mirror and The Sun news. This researcher found that many writers in the United Kingdom are tending in using colloquial languages such as slang and jargon in news reporting. Using slang in the text news is better than jargon in order to make readers understand more the content. Rakhmatova (2020) believed that using the jargon term will make the reader to go in depth in that subject matter. In other words, the reader must refer to the dictionary, even need to have special knowledge for that news. The researcher also explained that the use of the jargon term will make the readers lost their interest, but that it is difficult not to be used by writers.

For health article, a study by Ghazali and Omar (2014) showed that Indian adolescents, $86 \%$, have most likely chosen and read the health article in the press, as compared to Malay (55\%) and Chinese youth (37\%). This is because the display of health articles in the press is easier and not difficult to understand as compared with scientific books. In terms of the language used in writing health articles, a study by Hassan et al. (2017) found that the helpful use of language is determined by the accurate words choose, significant and easy to understand, clear formation sentences and contain suitable descriptions. 
The conclusions from several previous studies that have been conducted, researchers found that there are still gaps related to the study of audience dependence in the press, in term of health articles and acceptance of language aspects. In fact, the press is one of the mediums in distributing information to the public, but to what extent the message can be conveyed and understand by the public has still been an issue. Knowing this fact, it is relevant to discuss the audience's acceptance of the press to educate and open reader thoughts as well as help in language spreading.

\section{Methodology}

This study was conducted using two methods, namely field study (80\%) and content analysis (20\%). In the context of field study, the researcher distributed questionnaires to 50 respondents among the athletes of Universiti Putra Malaysia (UPM) who have / are representing universities, states or country in any tournament from within / outside the country. In generating the components in the questionnaire, the researcher analyzed the health articles content, namely Berita Harian (BH) and Utusan Malaysia (UM) newspapers published in October 2016 until November 2016 as the content analysis method. The questionnaire components are produced based on Waterhouse (1989) approach with related to the language features of journalistic writing and modified from the questions in the questionnaire form that produced by Ahmad Ghazali and Omar (2014).

There are twelve (12) language features of journalism writing based on Waterhouse (1989), namely using specific words, not generally; use concrete words, not abstract; use common words, uncommon words; and use the statement positively, not negatively. Then, avoid using dramatic and emotional words; avoid the use of linked words to express a simple meaning; avoid using words that carry the same meaning; avoid the use of words that indicate uncertainty; and avoid using unclear words in expressing a quantity. Besides, Waterhouse (1989) also mentioned the other features such as avoid excessive descriptions; use correct spelling and meaning words; and avoid the use of jargon and cliché words.

Athletes' dependence on newspaper health articles is measured by respondent's acceptance of newspaper health articles to obtain health information. There are 15 items were submitted in the questionnaire to answer the second objective of this study. The findings of the study were analyzed with 'Statistical Package for Social Science' (SPSS) and described qualitatively to present the extent of athletes' dependence on newspaper health articles to obtain health information related and their acceptance of use the language of writing health articles in newspapers. Each component presented in the questionnaire was measured in five (5) point Likert scale, namely 1 (strongly disagree, SD), 2 (disagree, D), 3 (moderate, M), 4 (agree, A) and 5 (strongly agree, SA) (Budiaji, 2013).

For the data analysis, the form of a mean interval scale table is done in order to show the level of dependence and acceptance of respondents. The scale indicates with very good, good, medium, weak and very weak (Levin \& Rubin, 2000) and descriptively described. The following is the calculating formula for mean interval scale:

$$
\text { Mean interval scale }=\frac{\text { Highest value }- \text { Lowest value }}{\text { Number of interval }}
$$

(Source: Hamzah et al., 2013)

Based on the above formula, five (5) is the highest value and the lowest value is one (1) in Likert scale. Thus, the calculation of mean interval scale as follows:

$$
\text { Mean interval scale }=\frac{5-1}{5}
$$




$$
\text { Mean interval scale }=\quad 0.8
$$

Table 1 shows the level of dependence and acceptance of respondents based on mean interval scale:

Table 1: Score level of dependence and acceptance of respondents

\begin{tabular}{cc}
\hline Mean Interval Scale & Level of Acceptance \\
\hline $4.21-5.00$ & Very good \\
$3.41-4.20$ & Good \\
$2.61-3.40$ & Medium \\
$1.81-2.60$ & Weak \\
$1.00-1.80$ & Very week \\
\hline
\end{tabular}

(Source: Hamzah et al., 2013)

The mean score calculation for the level of dependence and acceptance of the respondents for the language used of writing health articles has been done in this study. The calculation formula for the mean score for each component in the questionnaire are exemplified below:

$$
\begin{aligned}
\text { Mean score } & =\frac{\sum(\text { Scale } \times \mathrm{n})}{\mathrm{N}} \\
\mathrm{n} & =\quad \text { Number of respondents } \\
\mathrm{N} & =\quad \text { Total number of respondents }
\end{aligned}
$$

(Source: Hamzah et al., 2013) The mean score obtained will determine the final findings of this study to see the level of dependence of athletes' acceptance of health articles and the language used of writing health articles.

\section{Result and Discussion}

This section discusses the results of the study obtained based on the demographics of the respondents, the dependence of the respondents on the newspaper health articles and the analysis of the respondent's acceptance of the language used of writing health articles in the newspaper.

\section{Demographic Profile of the Respondents}

The demographics of the respondents discussed in this paper include year of study, age distribution, gender and race. Based on Table 2, the number of respondents for each year of study shows a balanced number. The majority of the respondents in this study were in a Year 3 study, which was 14 people, 28\%. Meanwhile, there were 13 respondents who in Year 4 study, 26\%, 12 respondents who in Year 1 study, 24\% and 11 respondents who in Year 2 study, $22 \%$. In terms of gender of the respondents, the number of female respondents is more than the male respondents who were involved in this study. The total number of male respondents in this study is 23 people, $46 \%$. Meanwhile, the total number of female respondents is 27 people, $54 \%$. 
Table 2: Demographic Information of the Respondents

\begin{tabular}{lcc}
\hline \multicolumn{1}{c}{ Profile } & Frequency & Percentage (\%) \\
\hline $\begin{array}{c}\text { Year of Study } \\
\text { Year 1 }\end{array}$ & 12 & 24 \\
Year 2 & 11 & 22 \\
Year 3 & 14 & 28 \\
Year 4 & 13 & 26 \\
Gender & & \\
$\quad$ Male & 23 & 46 \\
Female & 27 & 54 \\
$\quad$ & & \\
Age $\quad$ & \\
$\quad$ Below 20 years old & 12 & 24 \\
21 to 24 years old & 24 & 48 \\
Above 25 years old & 14 & 28 \\
Race & & \\
$\quad$ Malay & 32 & 64 \\
$\quad$ Chinese & 6 & 12 \\
Indian & 8 & 16 \\
Others & 4 & 8 \\
\hline
\end{tabular}

Besides, the age groups of the respondents involved in the study are diverse. The age of the respondents in this study were classified into three (3) level, which is below 20 years old, 21 to 24 years old and above 25 years old. Statistically, the majority of the respondents aged 21 to 24 years old, shows the highest involvement, which is 24 people, $48 \%$ as compared to the respondents aged above 25 years old, 14 people (28\%) and 12 people who were below 20 years old, $24 \%$. In terms of race, most of the respondents are Malays with the highest number recorded which is 32 people, 64\%. Followed by the Indians, which is 8 people, $16 \%$. Meanwhile, the Chinese and others races show the total of 6 and 4 people respectively. Specifically, for other races involved in this study, which were four respondents who were 2 Kadazans and 2 Ibans.

\section{Respondents' Dependence on Newspaper Health Articles}

This study was conducted to examine the extent of the dependence of respondents (athletes) to obtain health information through on the special segments of health articles in the press. Hence, there is one question stated in a questionnaire related the extent to which athletes' dependence on newspaper health articles to obtain health information. Table 3 shows the findings analysis of this study.

Table 3: Respondents' Dependence on Newspaper Health Articles

\begin{tabular}{|c|c|c|c|c|c|c|c|}
\hline \multirow{2}{*}{ Item } & \multicolumn{5}{|c|}{ Likert Scale } & \multirow{2}{*}{$\begin{array}{l}\text { Mean } \\
\text { Score }\end{array}$} & \multirow{2}{*}{ SD } \\
\hline & 1 & 2 & 3 & 4 & 5 & & \\
\hline $\begin{array}{c}\text { Do health articles in the press help you obtain } \\
\text { health information? }\end{array}$ & - & - & 6 & 26 & 18 & 4.24 & 0.65 \\
\hline \multicolumn{6}{|c|}{ The level of athlete's dependence on writing health articles } & \multicolumn{2}{|c|}{ Very Good } \\
\hline
\end{tabular}


The table 3 above shows that 18 respondents (36\%) gave a 5 scale (VG) which indicate that health article in the press help them obtain health information. Besides, 26 respondents $(52 \%)$ in this study gave a 4 scale $(G)$ and 6 respondents (12\%) gave a 3 scale $(M)$ for their dependence on the newspaper health articles. In addition, the mean score in this study presents the level of dependence of the respondents in the newspaper health article to obtain health information. Thus, the mean score result of 4.24 is very good (standard deviation: 0.65).

This shows that most of the athletes prefer to obtain health information through the health articles in the press as their reading materials. This finding can be supported with a study done by Ghazali and Omar (2014) which stated that the readers able to accept or reject the newspaper in order to meet their needs are depending on the newspaper content that have various dimensions of the material published. Besides, de Fleur and Ball-Rokeach (1992) explain that, the stronger the audience's dependence on the media, the greater the impact it has on their cognitive, emotional and behavioral aspects. Changes on cognitive, feelings and behaviors among the audience can be predictable when the level of dependence on the information presented is very high (de Fleur and Ball-Rokeach, 1992).

Therefore, the higher the audience's dependence on newspaper health articles, the more they obtain the information. It indirectly affects the cognitive, feelings and behavior of the audience. This is also supported through a study done by Zawawi and Chang (2013) that any information received by the audience through the media will change their cognition and expression due to the nature of journalism writing itself, which indirectly form general opinions and views on the subject matters through the information distribution.

\section{Audience Acceptance of the Language of Health Article Writing}

Based on the above findings, this study concluded that the acceptance of respondents (athletes) to obtain health information from the press is very good. In addition, this study also to see the extent to which respondents (athletes) accept the language used in writing health articles in newspapers. The approach, namely the Characteristics of the Language of Journalism Writing portrayed by Waterhouse (1989) shows the features on the language aspect of health article writing. There are twelve (12) language features stated which is using specific words, not generally; use concrete words, not abstract; use common words, uncommon words; and use the statement positively, not negatively. Then, avoid using dramatic and emotional words; avoid the use of linked words to express a simple meaning; avoid using words that carry the same meaning; avoid the use of words that indicate uncertainty; and avoid using unclear words in expressing a quantity. Besides, Waterhouse (1989) also mentioned the other features such as avoid excessive descriptions; use correct spelling and meaning words; and avoid the use of jargon and cliché words.

Therefore, to show the level of acceptance of respondents to the language used of writing health articles in the newspaper, fifteen (15) items have been stated in the questionnaire to analyze the extent of acceptance of respondents (athletes) related to the use of language in writing health articles in newspapers. The items stated in the questionnaire were modified and refined based on the twelve (12) language features of journalism writing portrayed by Waterhouse (1989). The fifteen (15) items stated meeting the sentence formation, use of words, title writing, rewording and clarity of content in writing health articles. Hence, Table 4 below exemplify the result of the level of respondent's acceptance of the language used of health articles writing. The mean score calculation for fifteen (15) items are itemized in order to facilitate the process for each item. 
Table 4: The Level of Respondent's Acceptance of the Language Used of Health Articles Writing

\begin{tabular}{|c|c|c|c|c|}
\hline No. & Item & $\begin{array}{l}\text { Mean } \\
\text { Score }\end{array}$ & SD & $\begin{array}{c}\text { Level of } \\
\text { Acceptance }\end{array}$ \\
\hline 1. & $\begin{array}{l}\text { I can well understand the language used in health } \\
\text { articles writing when reading the newspaper. }\end{array}$ & 4.24 & 0.51 & Very Good \\
\hline 2. & $\begin{array}{l}\text { I discover the language used in a health article } \\
\text { writing is well presented its contents. }\end{array}$ & 4.26 & 0.42 & Very Good \\
\hline 3. & $\begin{array}{l}\text { The word used in health articles writing is a specific, } \\
\text { not general. }\end{array}$ & 4.04 & 0.60 & Good \\
\hline 4. & $\begin{array}{l}\text { The language used in the title of the health article } \\
\text { indirectly describe the content. }\end{array}$ & 4.10 & 0.67 & Good \\
\hline 5. & $\begin{array}{l}\text { Sometimes, a health article writing contains jargon } \\
\text { terms (technical terms). }\end{array}$ & 4.58 & 0.49 & Very Good \\
\hline 6. & $\begin{array}{l}\text { The words and sentences form used in health articles } \\
\text { writing complies with Malay grammar. }\end{array}$ & 3.28 & 1.30 & Medium \\
\hline 7. & $\begin{array}{l}\text { The language used in health articles can influence my } \\
\text { understanding. }\end{array}$ & 4.22 & 0.54 & Very Good \\
\hline 8. & $\begin{array}{l}\text { The language used in explaining the content of } \\
\text { health article gave me new information. }\end{array}$ & 4.34 & 0.59 & Very Good \\
\hline 9. & $\begin{array}{l}\text { The language used in health article writing affects } \\
\text { my everyday language use. }\end{array}$ & 4.30 & 0.81 & Very Good \\
\hline 10. & $\begin{array}{l}\text { I do not have any problem understand the words and } \\
\text { sentences used in health articles writing. }\end{array}$ & 3.74 & 1.09 & Good \\
\hline 11. & $\begin{array}{l}\text { The words selected used in a health article is positive } \\
\text { and accurate, rather than dramatic and emotive. }\end{array}$ & 4.22 & 0.70 & Very Good \\
\hline 12. & $\begin{array}{l}\text { I will find the meaning of a word or term that I do not } \\
\text { know. }\end{array}$ & 3.16 & 0.37 & Medium \\
\hline 13. & $\begin{array}{l}\text { My vocabulary improved after reading health article } \\
\text { writing in the newspaper. }\end{array}$ & 3.96 & 0.60 & Good \\
\hline 14. & $\begin{array}{l}\text { The language used is accordance with health article } \\
\text { content. }\end{array}$ & 4.46 & 0.54 & Very Good \\
\hline \multirow[t]{2}{*}{15.} & $\begin{array}{l}\text { The language and content used in health articles } \\
\text { writing are able to influence my thoughts. }\end{array}$ & 4.56 & 0.49 & Very Good \\
\hline & $\begin{array}{c}\text { Level of Respondents' Acceptance of the Language } \\
\text { Used of Article Writing }\end{array}$ & 4.09 & 4.41 & Good \\
\hline
\end{tabular}

**SD = Standard Deviation

Based on Table 4 above, the level of respondent's acceptance of the language used of health articles writing in the press is at a good level, with a mean score of 4.09 (standard deviation: 4.41). Most of the respondents gave a positive response, although there are two items that show the level of acceptance of respondents is at a moderate level (items 6 and 12). Therefore, this study concludes that the acceptance of respondents (athletes) to the language used of health articles writing in the press is at a good level. These findings indicate that the language used in health articles writing is able to well explain the content to the respondents. The respondents also agreed that the language used in health articles writing is able to influence their thoughts (item 15, mean score: 4.56; level: very good). These findings 
can be supported with the findings obtained by Sha'ri (2010) that the use of accurate, standard and novel language will produce influential and interesting journalistic writing that can be remembered by readers.

The results of this study also found that the use of jargon words or terms in health articles writing is very high and the level of respondents' acceptance is very good. This shows that in the field of health or medicine, most of the health articles writing in the newspaper are often uses jargon words or terms to explain the information to the audience. However, the respondents (athletes) in this study stated that their frequency to find the meaning of words or terms that they do not understand is at a moderate level. Therefore, this study believes that the use of jargon words or terms in health articles writing should be reduced and the authors are advised to find clearer and easier word or term to be used in the content. Thus, the articles will be well understood by the respondents. The author can refer to the website, namely Pusat Rujukan Persuratan Melayu (http://prpm.dbp.gov.my/) to get the right words / jargon terms in Malay. Yaakob (2008) explains that the language used in journalistic writing should be a language that is easily understood by the public. According to Malek (2016), a word can be soothing, painful, inspiring, degrading, distorting, unifying and separating.

\section{Conclusion}

In a conclusion, the press is one of the options among athletes to get health information. Special segments of health articles in newspapers were found to meet the athletes' need to obtain health information. The findings of this study show that the level of dependence of athletes in the newspaper health articles is very good with a mean score of 4.24 (standard deviation: 0.65 ). In terms of the athletes' acceptance of the language used of health article writing, the findings show that their level of acceptance is at a good level with a mean score of 4.09 (standard deviation: 4.41). Therefore, to ensure the credibility of the newspaper as the main reading material among the audience, especially athletes, publishers need to focus more and appropriate on the health segments, especially on information, as the newspaper is a closest channel to the public. Most of the athletes recognize and agree that the language used is easy to understand and able to affect their thought. The language used in newspaper should be maintained so that the level of readability is sustained and the content can be understood, appreciated and have cognitive effect to audience's feelings and behavior.

\section{Acknowledgement}

The researcher would like to acknowledge Universiti Putra Malaysia for sponsoring the implementation of this study under the GP-IPS / 2017/9515800 Grant. The researcher would also like to thank all the respondents who cooperated in the implementation of this study.

\section{References}

Ghani, M. R. A., \& Ibrahim, F. (1987). Objektiviti bahasa dalam kewartawanan. Jurnal Komunikasi, 3(1), 13-25.

Wahab, K. A., \& Hamid, Z. (2015). Hambatan memahami bahasa: satu penelitian ke atas teks berita dalam talian berbahasa Indonesia, Tempo.Co. Jurnal Komunikasi, 31(2), 493-514.

Wahab, H. A. (2012). Aspek kelewahan dalam laporan akhbar atas talian. Issues in Languages Studies, 1(2), 24-31.

Adnan, M. H. (2015). Peranan media massa memartabatkan integriti nasional. Jurnal Komunikasi Borneo, 2 (1), 57-74. 
Ghazali, A. H. A., \& Omar, S. Z. (2014). Keperluan pembaca remaja terhadap kandungan akhbar. Jurnal Komunikasi, Malaysian Journal of Communication, 30 (Special Issue), 17-28.

Amir, J. (2005). Dari budaya ke media: mengangkat suara pinggiran di Sarawak. Kota Samarahan: The Sarawak Press Sdn Bhd.

Amir, J. (2006). Buat duit dengan menulis. Bukit Tinggi: PTS Profesional Publishing Sdn Bhd.

Awang, A. (2015). Pengaruh media dalam dialog kehidupan: Perspektif pengalaman saudara baru. Jurnal Komunikasi, 31(2), 47-60.

Budiaji, W. (2013). Skala pengukuran dan jumlah respon skala likert. Jurnal IImu Pertanian dan Perikanan, 2(2), 127-133.

De Fleur, M. L., \& Ball-Rokeach, S. (1992). Teori komunikasi massa. Kuala Lumpur: Dewan Bahasa dan Pustaka.

Fadzillah, K. A. H. (2016). Bahasa dalam penulisan rencana. Dewan Bahasa, 16 (8), 49-52.

Hamzah, M. S. G., Paim, L., Haron, S. A., \& Abdullah, M. F. N. L. (2013). Buku panduan pembinaan instrumen "Anda dan Kepenggunaan". Tanjung Malim, Perak: Emeritus Publications.

Hassan, M. H. S. (2017). Penggunaan bahasa dalam rencana akhbar (Master's thesis, Universiti Putra Malaysia).

Hassan, M. H. S., Sha'ri, S. N., Ayub, N. A., \& Yaakob, N. A. (2017). Strategi Bahasa Rencana Kesihatan dalam Akhbar Menggalakkan Gaya Hidup Sihat. Presented at Seminar Antarabangsa Psikolinguistik Kali Ke-4, Hotel Kota Kinabalu, Sabah).

Idrus, A. I., \& Hamzah, Z. A. Z. (2011). Analisis kesilapan dalam laporan media: Morfologi dan sintaksis. In Kamaruddin, K., Sujud, A., Hamzah, Z. A. Z., \& Rahman, S. R. (Eds.). Kelestarian Bahasa: Satu Rumpun Satu Ikatan (pp. 18-31). Serdang: Penerbit UPM.

Ismail, A. (2008). Komunikasi Risiko: Analisis Kandungan Berita Merokok di dalam Media Cetak. In Che Su Mustaffa, Hassan Abu Bakar \& Bahtiar Mohamad (Eds.). Isu-isu Komunikasi di Malaysia: Aplikasi Penelitian Empiri (pp. 1-19). Petaling Jaya: PearsonMalaysia Sdn Bhd.

Ismail, M. H., \& Rajab, M. K. N. A. (2010). Penilaian tahap prestasi kecergasan fizikal berasaskan kesihatan bagi atlet bola tampar SUKMA 2008 (Unpublished manuscript). Department of Education, Universiti Teknologi Malaysia, Malaysia.

Ismail, S., \& Adnan, H. M. (2011). Profil ruangan sukan dalam akhbar Utusan Malaysia dan Berita Harian. Jurnal Pengajian Media Malaysia, 13(2), 75-91.

Itule, B. D., \& Anderson, D. A. (2007). News writing and reporting for today media. New York: McGraw-Hill International Editions.

Levin, R. I., \& Rubin, D. S. (2000). Statistik untuk pengurusan edisi ketujuh (Susila Munisamy \& Halimah Awang, Trans.). Petaling Jaya: Pearson Education Asia Pte. Ltd.

Malek, M. (2016). Serlahan kebitaraan bangsa. Dewan Bahasa, 16(10), 3.

Masri, S., \& Ayob, R. (2002). Komunikasi Kewartawanan: Penulisan berita, rencana dan ulasan. Kuala Lumpur: Utusan Pubication \& Distributors Sdn Bhd.

Ariffin, M. Y. A. (2010). Pendapat publik mengenai peranan media dalam menangani jenayah. Jurnal Pengajian Media Malaysia, 8(1), 57-72.

Zawawi, J. W. M., \& Chang, P. K. (2013). Penentuan bingkai berita keselamatan awam dari penelitian respon kognisi dan ekspresi audiens. Jurnal Komunikasi, 29(2), 141-158.

Mustaffa, N., Ibrahim, F., Samani, M. C., \& Rahim, M. H. A. (2010). Persepsi khalayak terhadap kredibiliti media di Malaysia. Jurnal e-Bangi, 5(2), 153-160. 
Rakhmatova, N. V. (2020). The usage of colloquial words in newspapers. Проблемы педагогики, 1, 37-38.

Samani, M.C. (1997). Penulisan rencana berkesan. Kuala Lumpur: Dewan Bahasa dan Pustaka.

Samani, M. C., Maliki, J., \& Rashid, N. A. (2011). Literasi media: Melahirkan pengguna media berpengetahuan. Jurnal Pengajian Media Malaysia, 13 (2), 41-64.

Sha'ri, S. N. (2010). Aplikasi teori dan format penyuntingan bahan linear dalam surat khabar bahasa Melayu (Doctoral dissertation, Universiti Putra Malaysia). Retrieved from http://psasir.upm.edu.my/12334/

Sha'ri, S. N., \& Hassan, M. H. S. (2016). Bahasa dan berita akhbar Tribun Putra dalam perkongsian maklmumat warga kampus di Universiti Putra Malaysia. Presented at the Persidangan Antarabangsa Sains Sosial Dan Kemanusiaan (PASAK), Kolej Universiti Islam Selangor (KUIM).

Somiah, V., Hamzah, A., Ariffin, M. Y. A., \& Aziz, A. A. (2010). Liputan berita tentang Indonesia di Malaysia: Analisis kandungan Utusan Malaysia dan Berita Harian. Malaysian Journal of Media Studies, 12(2), 53-67.

Suroso. (2010). Pemanfaatan ragam bahasa jurnalistik di media massa. Ucapan Forum Wartawan Yogyakarta 24 November 2010.

Waterhouse, K. (1989). Waterhouse on newspaper style. London: Penguin.

Yaakob, N. A. (2008). Retorik kewartawanan Melayu akbar Berita Harian. Kuala Lumpur: Dewan Bahasa dan Pustaka. 